Jacobson Glenn (Orcid ID: 0000-0002-3409-8769)

Hostrup Morten (Orcid ID: 0000-0002-6201-2483)

\title{
The salmeterol anomaly and the need for a urine threshold
}

\author{
Glenn A. Jacobson ${ }^{1}$ and Morten Hostrup ${ }^{2}$
}

${ }^{1}$ School of Pharmacy and Pharmacology, College of Health and Medicine, University of

Tasmania, Hobart, Australia

${ }^{2}$ Section of Integrative Physiology, Department of Nutrition Exercise and Sports, University of Copenhagen, Denmark

\section{Keywords}

doping, pharmacokinetics, muscle, respiratory, asthma, anabolic

This article has been accepted for publication and undergone full peer review but has not been through the copyediting, typesetting, pagination and proofreading process which may lead to differences between this version and the Version of Record. Please cite this article as doi: $10.1002 / \mathrm{dta} .2810$ 


\section{Running title: Salmeterol urine threshold}

Corresponding author:

Glenn A Jacobson PhD

School of Medicine,

\section{University of Tasmania}

Private Bag 26 Hobart, TAS 7001 Australia

Telephone No.: 61-03-62262190

Fax No.: $\quad 61-03-62262870$

E-mail address: glenn.jacobson@utas.edu.au 


\section{Abstract (250 words)}

Salmeterol is a long acting beta2-agonist (LABA) widely used for treatment of airways disease. There is evidence that beta2-agonists, including salmeterol, have the potential for performance enhancing effects when delivered at supratherapeutic doses. For this reason, all beta2-agonists are currently on the Prohibited List issued by the World Anti-Doping Agency (WADA) regardless of dosing route with some exemptions for inhaled salbutamol, formoterol, and salmeterol when used at therapeutic inhaled doses. For 2020, salmeterol use is permitted up to a therapeutic dosing threshold of $200 \mu \mathrm{g}$ daily, but unlike salbutamol and formoterol, there is an anomaly; currently there is no urine threshold to control for supratherapeutic dosing beyond this dosing threshold. Salmeterol, however, is reportable as an Adverse Analytical Finding (AAF) at levels above $10 \mathrm{ng} / \mathrm{ml}$. Complicating matters is that following inhalation, salmeterol parent drug is present at relatively low levels compared to other beta2-agonists due to rapid metabolism to the metabolite, alpha-hydroxysalmeterol, which is typically present at higher levels than parent drug. Moreover, peak parent drug levels following permitted therapeutic dosing are below the minimum required performance level (MRPL) of $10 \mathrm{ng} / \mathrm{ml}$ for salmeterol (50\% of the MRPL that analytical laboratories are required to meet for non-threshold beta2agonists), hence the presence of salmeterol may be unreported. For consistency, a urine threshold should be introduced for salmeterol as matter of priority, to balance the needs of athletes that use salmeterol therapeutically up to the agreed dosing threshold, with the need to control supratherapeutic dosing for doping intentions and athlete harm minimisation. 


\section{Introduction}

Salmeterol is a long acting beta2-agonist (LABA) that is widely used for the treatment of airway disease, particularly asthma. Salmeterol is usually delivered via metered dose inhaler (MDI) or dry powder inhaler (DPI) twice daily and is used as a "symptom controller" with a duration of action around 12 hours compared to the short-acting beta2-agonist (SABA) salbutamol with a duration of action around 4 hours. Salmeterol is also a chiral compound and is usually administered as the racemate (50:50 mixture of (R)- and (S)-salmeterol), with (R)salmeterol being the active enantiomer ${ }^{1}$. Enantiopure (R)-salmeterol is reportedly available for purchase online via chemical supply vendors.

There is solid evidence that members of the beta2-agonist drug class, including salmeterol, have the potential for performance enhancing effects when delivered at supratherapeutic doses. When administered at acute high doses, beta2-agonists can enhance muscle power and sprint performance ${ }^{2-8}$, and if taken for longer periods, they possesses muscle anabolic properties ${ }^{9-11}$, as recently reviewed ${ }^{12}$. For this reason, all beta2-agonists are on the 2020 Prohibited List issued by the World Anti-Doping Agency (WADA) ${ }^{13}$ regardless of dosing route - albeit with three exemptions. Salbutamol, formoterol, and salmeterol are allowed by inhalation at therapeutic doses up to a dosing threshold. The therapeutic dosing threshold for salmeterol is $200 \mu \mathrm{g}$ daily. However, unlike salbutamol and formoterol, there is no urine threshold for salmeterol. Despite being reportable at levels above $10 \mathrm{ng} / \mathrm{ml}$ (50\% of the Minimum Required Performance Level (MRPL) ${ }^{14}$, an unscrupulous athlete could inhale salmeterol at high doses with relative impunity for performance-enhancing purposes. 
Here we outline the potential for supratherapeutic misuse of salmeterol and argue that a urine threshold needs to be introduced as a matter of priority.

\section{Salmeterol as a performance enhancing drug}

Few studies have investigated the potential performance-enhancing effects of salmeterol in humans. Early work in athletes suggested that used acutely at therapeutic low doses $(50 \mu \mathrm{g})$, salmeterol did not enhance running performance, cycling anaerobic power or muscle strength 15,16. However, more recent work has demonstrated that daily inhaled treatment with salmeterol (100 $\mu \mathrm{g}$ twice daily) enhanced $30 \mathrm{~m}$ sprint performance during a period of 5 weeks in combination with a power and strength program ${ }^{17}$. To our best knowledge, no study has been performed in humans that had muscle hypertrophy as an outcome measure, but studies in rodents show that salmeterol possesses anabolic properties. Thus, there appears to be beneficial effects in rat muscle ${ }^{18}$ as well as rat dosing studies ${ }^{19}$. The work by Moore et al ${ }^{19}$ was based on the theory that a long duration of action is required for beta2-agonists to evoke an anabolic response, and compared the potent anabolic relatively non-selective beta2-agonist clenbuterol with salmeterol by equimolar dosing of rats via different routes of administration. Given orally, salmeterol caused significant increases in body and carcass weight, and in the mass of mixed fibre gastrocnemius/plantaris and tibialis anterior muscles, but no increase in slow-twitch soleus muscles ${ }^{19}$. These effects were similar to that observed with clenbuterol, apart from an additional response seen in soleus muscle. However, when given by infusion, salmeterol demonstrated a dramatic increase in soleus muscle mass. These results indicate that the anabolic potency of salmeterol in vivo is dependent on the route of administration; this is highly relevant to dosing via the inhaled route where first-pass metabolism is limited to the swallowed fraction. The other findings from this work were that slow-twitch muscles are less sensitive than mixed-fibre muscles, and observance of ergogenic effects in humans may be 
muscle/exercise test specific, possibly accounting for some of the negative findings in older athlete studies. Ryall et al ${ }^{20}$ examined the effect of intra-peritoneal injections of formoterol and salmeterol in rats for therapeutic applications in muscle wasting disease. It was found that while formoterol was more potent than salmeterol, salmeterol demonstrated greater muscle hypertrophy $(\sim 12 \%)$ in the extensor digitorum longus (fast twitch) and soleus (slow twitch) muscle compared to formoterol, and that both drugs used at around 25 microgram $/ \mathrm{kg} / \mathrm{day}$ are capable of eliciting skeletal muscle hypertrophy with minimal effects on heart muscle. A summary of muscle studies is shown in Table 1.

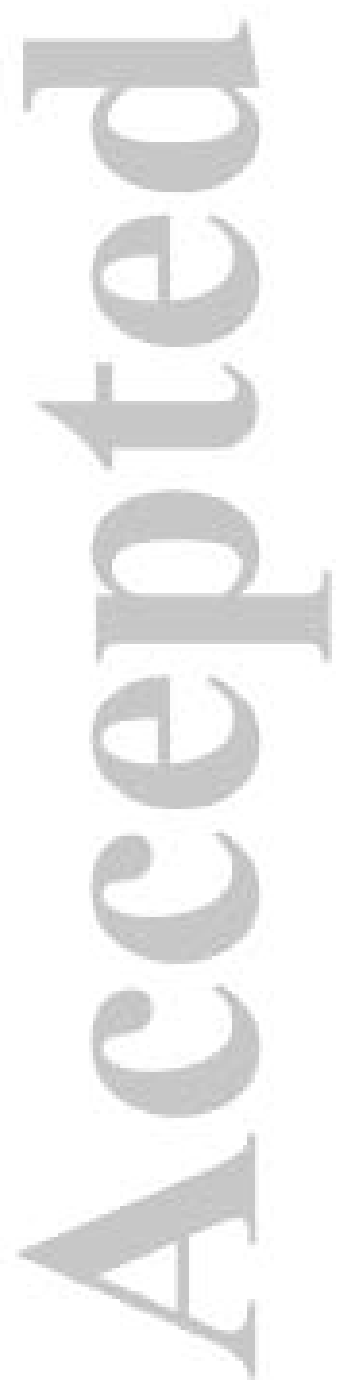




\section{Salmeterol on the Prohibited List}

Salmeterol, like formoterol and salbutamol, is permitted to be used via inhalation under certain dosing thresholds to allow athletes with asthma to compete. These thresholds are designed to distinguish between therapeutic dosing (need to treat asthma symptoms) and supratherapeutic dosing (where a performance benefit may be obtained).

Thresholds for salbutamol and formoterol consist of dosing via the inhalation route (metered dose inhaler) with a maximum permitted dose in a 12 and 24 hour period, respectively ${ }^{13}$, importantly with corresponding urine thresholds ${ }^{22}$ to limit the potential for supratherapeutic dosing for doping purposes. For salmeterol, there is only a dosing threshold with no corresponding urine threshold. Despite the drug being detectable in urine, this effectively means there is no practical way to limit supratherapeutic dosing other than relying on an athlete's honesty to report their dose in the previous 24 hours. This is a similar situation to the SABA terbutaline when administered under a Therapeutic Use Exemption (TUE) ${ }^{23}$.

A review of anti-doping figures for the three permitted beta2-agonists, salbutamol, formoterol, and salmeterol, from publicly available sources indicate that there are only a relatively small number of Adverse Analytical Findings (AAFs) attributable to salmeterol as shown in Table 2.

Salmeterol, present as the un-metabolised parent drug, is reportable as an AAF at levels above $10 \mathrm{ng} / \mathrm{ml}$ (50\% of the Minimum Required Performance Level (MRPL)) ${ }^{14}$. From 2010, there has been a significant change in formoterol AAFs per year, a result of formoterol being permitted to be used with corresponding dosing and urine threshold from 2012 onwards. While there appears to be low numbers of salmeterol AAFs, this is most likely due to differences in the pharmacokinetics of salmeterol compared to salbutamol and formoterol, which results in very low urine concentrations as discussed below. 


\section{Urine levels following dosing}

Only a few studies have reported urinary levels of salmeterol or the alpha-hydroxy metabolite, with reports in horses ${ }^{25,26}$ and humans ${ }^{27-29}$. Data on salmeterol urinary levels from human studies are summarised in Table 3.

Part of the reason for the lack of data is the relatively low concentrations observed in urine meaning the assay is technically demanding, particularly for routine screening. As reported by Hostrup et $\mathrm{al}^{27}$, the median urine concentration of the alpha-hydroxysalmeterol metabolite after 4 hours was $2.9 \mathrm{ng} / \mathrm{ml}$, and the median salmeterol concentration was around 8-fold lower at $0.38 \mathrm{ng} / \mathrm{ml}$ in non-athletes male subjects who inhaled a 100 microgram dose via a DPI device in resting conditions.

A survey of 7045 routine doping urine samples collected over 1 year, demonstrated that only a small number $(0.6 \%, 45 / 7045$ samples $)$ contained salmeterol, and only eight had levels higher than $0.5 \mathrm{ng} / \mathrm{ml}$, with the two highest at $1.81 \mathrm{ng} / \mathrm{ml}$ and $1.29 \mathrm{ng} / \mathrm{ml}^{28}$. This was similar to the maximum observed concentration in an accompanying excretion volunteer study (1.27 $\mathrm{ng} / \mathrm{ml})^{28}$. The most remarkable result was that only 8 samples had a concentration higher than $0.5 \mathrm{ng} / \mathrm{ml}$, meaning that $87 \%$ of the samples had a concentration below the lower limit of quantification of the method. Interestingly from the same manuscript in a volunteer study; in 6 subjects who inhaled an acute dose of 100 microgram salmeterol (MDI device), nine samples $(50 \%, 9 / 18$ samples) were above $0.5 \mathrm{ng} / \mathrm{ml}$ compared to $18 \%(8 / 45)$ in the doping control figures where salmeterol was detected. This difference should be largely attributed to sampling outside the time of peak excretion, highlighting that doping control figures cannot be meaningfully compared with clinical pharmacokinetics studies.

In terms of published clinical studies, there are only two other studies ${ }^{27,30}$. Our salmeterol study ${ }^{30}$ demonstrated a median (range) of $0.08(3) \mathrm{ng} / \mathrm{ml}$ for a $50 \mu \mathrm{g}$ dose, and $2.1(5) \mathrm{ng} / \mathrm{ml}$ for 
a $200 \mu \mathrm{g}$ dose both with urine at $2 \mathrm{~h}$. Both of these doses have not been previously reported so any direct comparison is challenging. Studies at a $100 \mu \mathrm{g}$ dose have been reported ${ }^{27,28}$ but unlike salbutamol, there is no information on the linearity of the dose-urine concentration relationship ${ }^{31}$ so concentrations cannot be extrapolated either up or down. Based on a comparison of the three different dosages now reported $(50,100,200 \mu \mathrm{g})$, it appears that this relationship may not be linear at least for peak levels (Figure 1) and appears also highly variable - this is a different situation to salbutamol which is metabolised via a different pathway and is linear ${ }^{31}$. Observation of our previous data ${ }^{30}$ shows that at the $50 \mu \mathrm{g}$ dose, one subject had noticeably high levels compared to the other subjects, but the remainder were less than 0.16 $\mathrm{ng} / \mathrm{ml}$ which is less than half the median observed by Hostrup et al ${ }^{27}$ and less than a quarter of that for Deventer et al ${ }^{28}$. At the $200 \mu \mathrm{g}$ dose, there was another high outlier $(5.7 \mathrm{ng} / \mathrm{ml})$, but the remainder of samples were below $3.5 \mathrm{ng} / \mathrm{ml}$, with a median of 2.1 which was higher than both the Hostrup et al ${ }^{27}$ (median 0.38) and Deventer et al ${ }^{28}$ (median of $0.64 \mathrm{ng} / \mathrm{ml}$ ) studies. Both the Hostrup et al ${ }^{27}$ and Deventer et al ${ }^{28}$ studies were half the dose. In addition, the Hostrup et al ${ }^{27}$ samples were corrected for SG whereas salmeterol samples from our study ${ }^{30}$ were not corrected for SG. In-house data from our laboratory reveal an inter-subject variability upwards of $50 \%$ for urine salmeterol levels, whereas the intra-subject variability is around $40 \%$ for urine levels, but only $20 \%$ for $0-12$-h excretion.

Given the extensive CYP3A4 metabolism of salmeterol, the large inter-subject variability may also be explained by inter-subject pharmacogenetic differences for this enzyme ${ }^{32}$, as well as significant potential for dietary inhibitors (well known CYP3A4 dietary inhibitors such as grapefruit juice etc.), which was not controlled in any of these urine levels studies. Like the other beta2-agonists, salbutamol and terbutaline, exercise and dehydration are likely to have a significant effect on urine levels and increase the chance of exceeding any threshold limits ${ }^{33,34}$. 
To account for this, the urine decision limits for threshold substances, such as salbutamol and formoterol, are adjusted to a USG of 1.020 if the urine samples exceed a USG of $1.018+0.002$ (the latter represent the maximum uncertainty for the USG measurement). Hence, if a threshold is to be introduced for salmeterol, the corresponding decision limit would be adjusted upwards for concentrated urine samples.

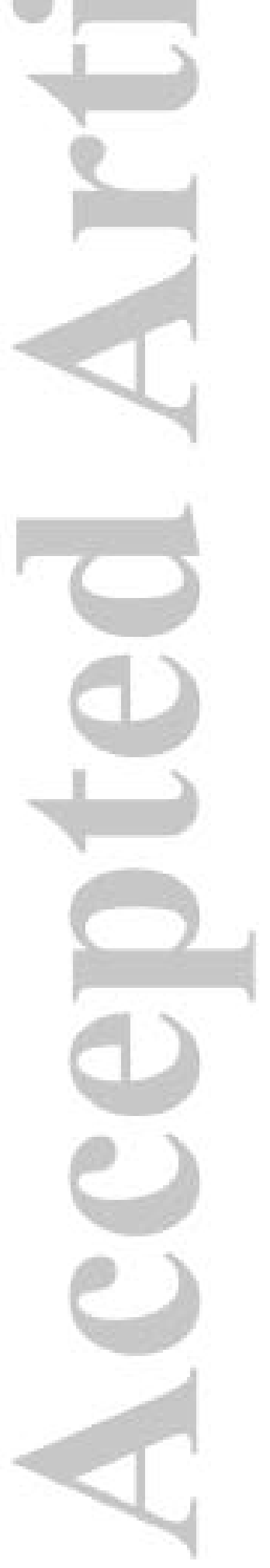




\section{The salmeterol anomaly}

Based on the observations that salmeterol possesses muscle anabolic effects in rodents, and that other beta2-agonists within the same drug class can enhance muscle power and sprint performance, abductive reasoning suggests that salmeterol's place on WADAs 2020 Prohibited

List is warranted. Unlike salbutamol and formoterol that are permitted to be used below a dosing threshold, along with a corresponding urine threshold to limit supratherapeutic dosing, salmeterol only has a dosing threshold with no published urine threshold.

The minimum required performance level (MRPL), is the minimum concentration of a prohibited substance, metabolite or marker that can be reliably detected and identified in routine daily operations, and is used for non-threshold substances. ${ }^{14}$ The basic premise of the MRPL is that it harmonises the analytical methods of performance for non-threshold substances across the world. The MRPL for the S3 beta2-agonist class is $20 \mathrm{ng} / \mathrm{ml}$, and salmeterol is reportable as an AAF at levels above $10 \mathrm{ng} / \mathrm{ml}$ (50\% of the Minimum Required Performance Level (MRPL). ${ }^{14}$ This level is around 5-10-fold higher than maximum levels typically observed following salmeterol inhalation therapy. The fact that salmeterol has a dosing threshold but no urine threshold ${ }^{22}$ appears an anomaly in itself, aside from the fact that even if salmeterol has a reporting limit (50\% MRPL), unlike salbutamol and formoterol, laboratories may not necessarily be capable of measuring salmeterol down to the required level where the active drug is likely to be found (Table 3). Similarly, while the active metabolite appears to be a suitable candidate to measure salmeterol via inhalation and thus act as a urine threshold analyte ${ }^{27}$, there is no provision to measure the alpha-hydroxysalmeterol metabolite, either as a threshold or non-threshold substance, and for this to be reported as an AAF.

To our knowledge there is no published research linking the seemingly arbitrary urine concentration of $10 \mathrm{ng} / \mathrm{ml}(50 \% \mathrm{MRPL})$ to the maximum dose threshold of $200 \mu \mathrm{g}$. Moreover, 
this $10 \mathrm{ng} / \mathrm{ml}$ level could be considered generous when considering peak levels from a maximal dose $(200 \mu \mathrm{g})$ from two studies have been $5.7 \mathrm{ng} / \mathrm{ml}$ (Table 3). This could potentially lead to a situation where an athlete could essentially use as much inhaled salmeterol as they wish, limited only by adverse effects. If an AAF did arise, it could be claimed that the result was attributable to maximum threshold dosing levels. The administration route could also be parenteral or oral if so desired. With no way of checking for dosing compliance using a urine threshold, supratherapeutic use could result in performance enhancements and athlete harm.

\section{Conclusion}

Salmeterol is likely to be performance enhancing in supratherapeutic doses and is allowed inand out of competition but since there is no urine threshold, there is currently no way of ensuring use is restricted to dosing thresholds apart from the seemingly arbitrary requirement for reporting at $10 \mathrm{ng} / \mathrm{ml}$. Despite some limitations, the urine thresholds introduced by WADA for salbutamol and formoterol to restrict supratherapeutic dosing works well for the vast majority of athletes who use beta2-agonists therapeutically under permitted regimens. For consistency, a urine threshold should also be introduced for salmeterol as matter of priority, to balance the needs of athletes that use salmeterol therapeutically up to the agreed dosing threshold, with the need to control supratherapeutic dosing for doping purposes and athlete harm minimisation. Further work would be required to ascertain whether the metabolite or parent drug would be the best candidate, and the apparent non-linear dose-urine concentration needs greater exploration.

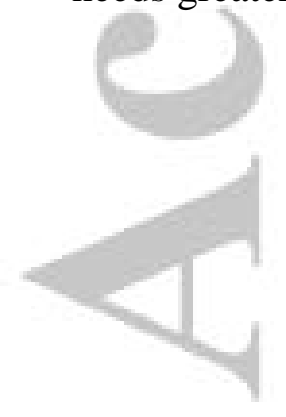




\section{Conflict of interest}

GJ and MH have provided independent scientific reports in anti-doping investigations involving beta2-agonists. Both authors are funded by independent research grants from WADA that pertains to beta2-agonist pharmacology and physiology of the related beta2-agonists

salbutamol, terbutaline and formoterol.

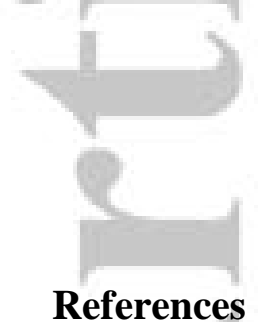

1. Jacobson GA, Fawcett JP. Beta2-agonist doping control and optical isomer challenges. Sports Medicine. 2016;46(12):1787-1795.

2. Collomp K, Le Panse B, Portier $\mathrm{H}$, et al. Effects of acute salbutamol intake during a Wingate test. Int J Sports Med. 2005;26(7):513-517.

3. Hostrup M, Kalsen A, Auchenberg M, Bangsbo J, Backer V. Effects of acute and 2-week administration of oral salbutamol on exercise performance and muscle strength in athletes. Scand J Med Sci Sports. 2014.

4. Hostrup M, Kalsen A, Bangsbo J, Hemmersbach P, Karlsson S, Backer V. High-dose inhaled terbutaline increases muscle strength and enhances maximal sprint performance in trained men. Eur J Appl Physiol. 2014;114(12):2499-2508.

5. Kalsen A, Hostrup M, Soderlund K, Karlsson S, Backer V, Bangsbo J. Inhaled Beta2-agonist Increases Power Output and Glycolysis during Sprinting in Men. Med Sci Sports Exerc. 2015.

6. Kalsen A, Hostrup M, Soderlund K, Karlsson S, Backer V, Bangsbo J. Inhaled Beta2-Agonist Increases Power Output and Glycolysis during Sprinting in Men. Med Sci Sports Exerc. 2016;48(1):39-48.

7. Martineau L, Horan MA, Rothwell NJ, Little RA. Salbutamol, a beta 2-adrenoceptor agonist, increases skeletal muscle strength in young men. Clin Sci (Lond). 1992;83(5):615-621.

8. van Baak MA, Mayer LH, Kempinski RE, Hartgens F. Effect of salbutamol on muscle strength and endurance performance in nonasthmatic men. Med Sci Sports Exerc. 2000;32(7):13001306.

9. Lemminger AK, Jessen S, Habib S, et al. Effect of beta2 -adrenergic agonist and resistance training on maximal oxygen uptake and muscle oxidative enzymes in men. Scand J Med Sci Sports. 2019.

10. Jessen S, Onslev J, Lemminger A, Backer V, Bangsbo J, Hostrup M. Hypertrophic effect of inhaled beta2 -agonist with and without concurrent exercise training: A randomized controlled trial. Scand J Med Sci Sports. 2018;28(10):2114-2122.

11. Hostrup $M$, Kalsen $A$, Onslev J, et al. Mechanisms underlying enhancements in muscle force and power output during maximal cycle ergometer exercise induced by chronic beta2adrenergic stimulation in men. J Appl Physiol (1985). 2015;119(5):475-486.

12. Hostrup $M$, Jacobson GA, Jessen $S$, Lemminger AK. Anabolic and lipolytic actions of beta2 agonists in humans and antidoping challenges. Drug Test Anal. 2020.

13. World Anti-Doping Agency. Prohibited List 2019. 2019. https://www.wadaama.org/en/resources/science-medicine/prohibited-list-documents. 
14. World Anti-Doping Agency. WADA Technical Document -TD2019MRPL. In. Minimum required performance levels for detection and identification of non-threshold substances.2019.

15. Morton AR, Joyce K, Papalia SM, Carroll NG, Fitch KD. Is salmeterol ergogenic? Clin J Sport Med. 1996;6(4):220-225.

16. Carlsen $\mathrm{KH}$, Ingjer $\mathrm{F}$, Kirkegaard $\mathrm{H}$, Thyness B. The effect of inhaled salbutamol and salmeterol on lung function and endurance performance in healthy well-trained athletes. Scand $\mathrm{J}$ Med Sci Sports. 1997;7(3):160-165.

17. Merlini M, Whyte G, Marcora S, Loosemore M, Chester N, Dickinson J. Improved Sprint Performance With Inhaled Long-Acting Beta2-Agonists Combined With Resistance Exercise. Int J Sports Physiol Perform. 2019:1-22.

18. Fredsted A, Gissel H, Ortenblad N, Clausen T. Effects of beta(2)-agonists on force during and following anoxia in rat extensor digitorum longus muscle. J Appl Physiol (1985). 2012;112(12):2057-2067.

19. Moore NG, Pegg GG, Sillence MN. Anabolic effects of the beta 2-adrenoceptor agonist salmeterol are dependent on route of administration. Am J Physiol. 1994;267(3 Pt 1):E475484.

20. Ryall JG, Sillence MN, Lynch GS. Systemic administration of beta2-adrenoceptor agonists, formoterol and salmeterol, elicit skeletal muscle hypertrophy in rats at micromolar doses. $\mathrm{Br}$ J Pharmacol. 2006;147(6):587-595.

21. Carbo N, Lopez-Soriano J, Tarrago T, et al. Comparative effects of beta2-adrenergic agonists on muscle waste associated with tumour growth. Cancer Lett. 1997;115(1):113-118.

22. World Anti-Doping Agency. WADA Technical Document -TD2019DL Version 2.

23. Jacobson GA, Hostrup M. Terbutaline: level the playing field for inhaled \&\#946;2-agonists by introducing a dosing and urine threshold. British Journal of Sports Medicine. 2017;51:13231324.

24. World Anti-Doping Agency. Anti-Doping Testing Figures Report. https://www.wadaama.org/en/resources/laboratories/anti-doping-testing-figures-report. Accessed September 302019.

25. Van Eenoo P, Deventer K, Delbeke F. Quantitative detection of salmeterol after inhalation in equine urine by liquid chromatography/tandem mass spectrometry. Rapid Commun Mass Spectrom. 2002;16(18):1755-1759.

26. Garcia P, Paris A, Gil J, Popot M, Bonnaire Y. Analysis of beta-agonists by HPLC/ESI-MS(n) in horse doping control. Biomed Chromatogr. 2011;25(1-2):147-154.

27. Hostrup $M$, Kalsen $A$, Elers $J$, et al. Urine concentrations of inhaled salmeterol and its metabolite alpha-hydroxysalmeterol in asthmatic and non-asthmatic subjects. J Sports Med Doping Stud. 2012;2:2:6.

28. Deventer K, Pozo O, Delbeke F, Van Eenoo P. Quantitative detection of inhaled salmeterol in human urine and relevance to doping control analysis. Ther Drug Monit. 2011;33(5):627-631.

29. Cazzola M, Testi R, Matera M. Clinical pharmacokinetics of salmeterol. Clin Pharmacokinet. 2002;41(1):19-30.

30. Jacobson GA, Hostrup M, Narkowicz CK, Nichols DS, Walters EH. Enantioselective disposition of $(\mathrm{R})$-salmeterol and (S)-salmeterol in urine following inhaled dosing and application to doping control. Drug Testing and Analysis. 2017;9(8):1262-1266.

31. Tomlinson HS, Corlett SA, Chrystyn H. Dose-response relationship and reproducibility of urinary salbutamol excretion during the first 30 min after an inhalation. Br J Clin Pharmacol. 2003;56(2):225-227.

32. Werk A, Cascorbi I. Functional gene variants of CYP3A4. Clin Pharmacol Ther. 2014;96(3):340348.

33. Haase C, Backer V, Kalsen A, Rzeppa S, Hemmersbach P, Hostrup M. The influence of exercise and dehydration on the urine concentrations of salbutamol after inhaled administration of 1600 microg salbutamol as a single dose in relation to doping analysis. Drug Test Anal. 2015.

This article is protected by copyright. All rights reserved. 
34. Kreiberg $M$, Becker $\mathrm{V}$, Jessen $\mathrm{S}$, et al. Influence of exercise in normal and hot ambient conditions on the pharmacokinetics of inhaled terbutaline in trained men. Scand J Med Sci Sports. 2017;27(7):692-703.

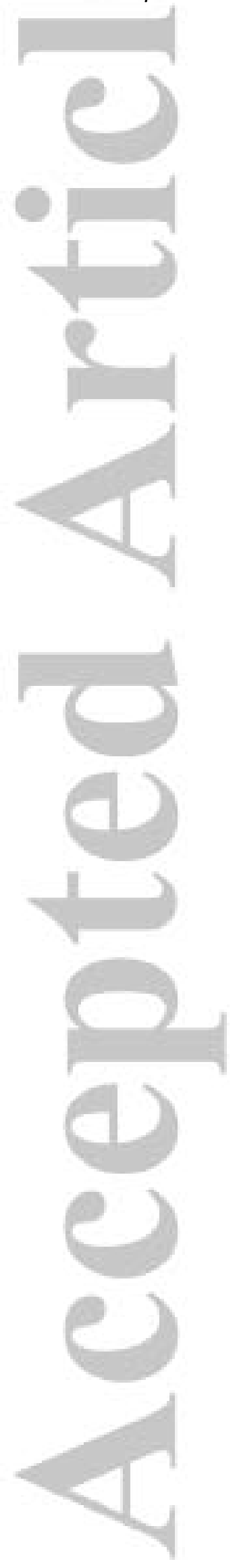

This article is protected by copyright. All rights reserved. 
Table 1. In vivo studies of salmeterol effects on muscle mass.

\begin{tabular}{|c|c|c|c|c|c|c|c|c|}
\hline \multirow[t]{2}{*}{ Study } & \multirow[t]{2}{*}{ Dose } & \multirow[t]{2}{*}{ Species } & \multirow[t]{2}{*}{ Duration } & \multicolumn{5}{|c|}{ Effect } \\
\hline & & & & $\begin{array}{l}\text { Tibialis anterior } \\
\text { (increased mass, mg } \\
\text { (\%) versus control) }\end{array}$ & $\begin{array}{l}\text { Gastrocnemius/ } \\
\text { plantaris } \\
\text { (increased mass, mg } \\
(\%) \text { versus control) }\end{array}$ & $\begin{array}{l}\text { Soleus } \\
\text { (increased mass, } \\
\mathrm{mg}(\%) \text { versus } \\
\text { control) }\end{array}$ & $\begin{array}{l}\text { Extensor } \\
\text { digitorum longus } \\
\text { (increased mass, } \\
\text { mg }(\%) \text { versus } \\
\text { control) }\end{array}$ & $\begin{array}{l}\text { Heart } \\
\text { (increased } \\
\text { mass, mg }(\%) \\
\text { versus } \\
\text { control) }\end{array}$ \\
\hline $\begin{array}{l}\text { Ryall et al. } \\
2006^{20}\end{array}$ & $\begin{array}{l}\text { Once daily } \\
\text { intraperitoneal } \\
\text { (ip) injection } \\
\mu \mathrm{g} / \mathrm{kg} / \mathrm{d} \\
1 \\
10 \\
25 \\
250 \\
500 \\
1000 \\
2500\end{array}$ & $\begin{array}{l}\text { Rats } \\
\text { (Fisher 344) } \\
270 \mathrm{~g}\end{array}$ & 4 weeks & - & - & $\begin{array}{l}\text { No effect } \\
5(5 \%) \\
9(9 \%) \\
20(21 \%) \\
27(28 \%) \\
26(27 \%) \\
27(28 \%)\end{array}$ & $\begin{array}{l}\text { No effect } \\
3(3 \%) \\
10(9 \%) \\
31(28 \%) \\
35(32 \%) \\
43(39 \%) \\
43(39 \%)\end{array}$ & $\begin{array}{l} \\
\text { No effect } \\
\text { No effect } \\
43(6 \%) \\
109(16 \%) \\
132(19 \%) \\
174(25 \%) \\
112(16 \%)\end{array}$ \\
\hline $\begin{array}{l}\text { Carbo et al } \\
(1997)^{21}\end{array}$ & $\begin{array}{l}\begin{array}{l}\text { Route of } \\
\text { administration } \\
\text { not specified }\end{array} \\
3.5 \mu \mathrm{mol} / \mathrm{kg} / \mathrm{d} \\
(1455 \mu \mathrm{g} / \mathrm{kg} / \mathrm{d})\end{array}$ & $\begin{array}{l}\begin{array}{l}\text { Rats } \\
\text { (Wistar) }\end{array} \\
\text { 100-150 g }\end{array}$ & 7 days & - & $75 \mathrm{mg} / 100 \mathrm{mg}(11 \%)$ & No effect & - & No effect \\
\hline Moore et al ${ }^{16}$ & $\begin{array}{l}\text { Oral } \\
120 \mu \mathrm{g} / \text { day } \\
2.4 \mathrm{mg} / \text { day }\end{array}$ & $\begin{array}{l}\text { Rats } \\
\text { (Wistar) } \\
\text { 140-190 g }\end{array}$ & 10 days & $\begin{array}{l}\text { No effect } \\
212(24 \%)^{*}\end{array}$ & $\begin{array}{l}\text { No effect } \\
655(25 \%)^{*}\end{array}$ & $\begin{array}{l}\text { No effect } \\
\text { No effect }\end{array}$ & $\begin{array}{l}\text { No effect } \\
\text { No effect }\end{array}$ & $\begin{array}{l}\text { No effect } \\
110(15 \%)^{*}\end{array}$ \\
\hline
\end{tabular}

This article is protected by copyright. All rights reserved. 


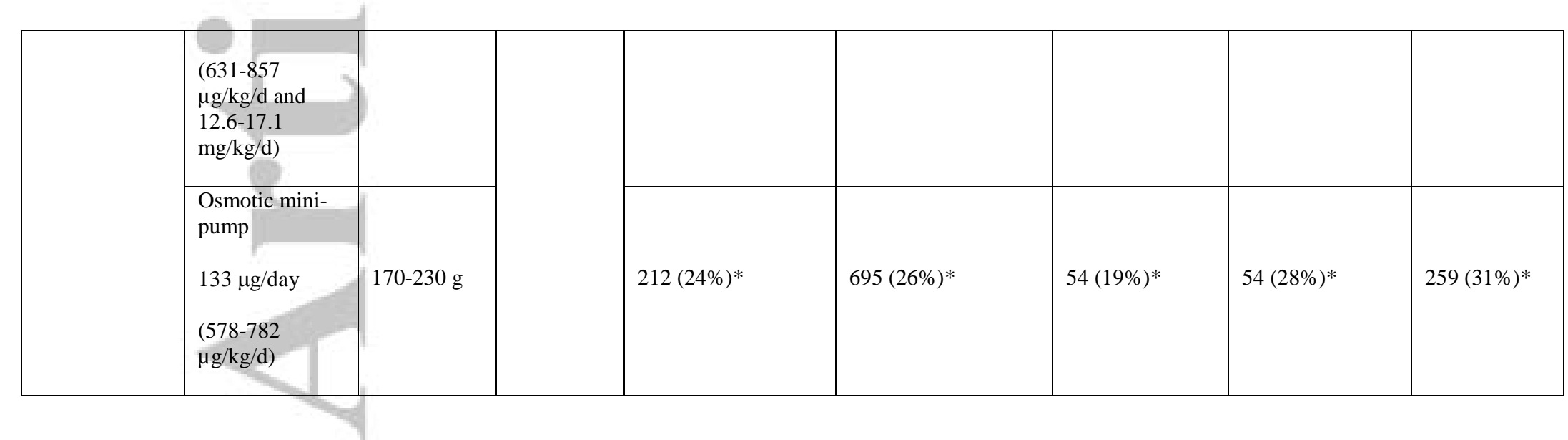

* Estimated from manuscript figures using ImageJ (https://imagej.nih.gov/ij/)

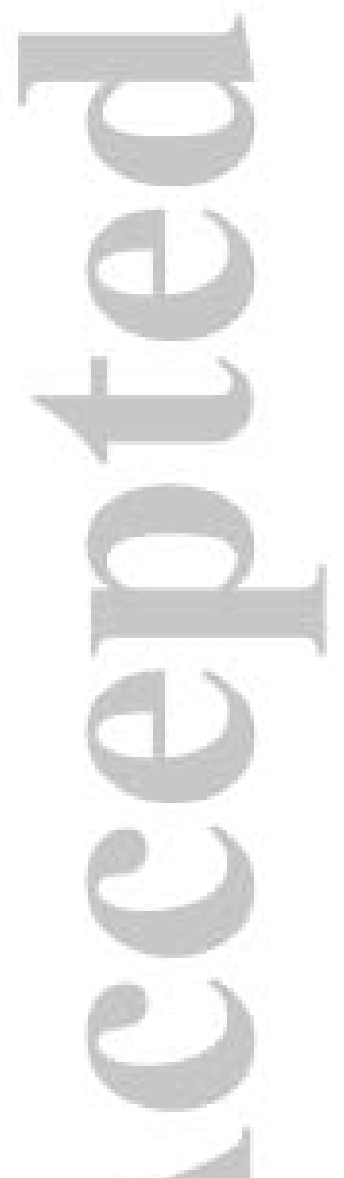


Table 2. Currently permitted beta2-agonists identified as Adverse Analytical Findings (AAFs) in the S3 Beta2-agonist drug class (all sports) from 2010-2017 ${ }^{24}$, reflecting the addition of a dosing and urine threshold for formoterol in 2012. *AAFs and ATFs (atypical finding)

\begin{tabular}{lcccccccc}
\hline & $2010^{*}$ & $2011^{*}$ & $2012^{*}$ & $2013^{*}$ & 2014 & 2015 & 2016 & 2017 \\
salbutamol & 9 & 6 & 6 & 11 & 8 & 16 & 15 & 12 \\
formoterol & 78 & 84 & 0 & 0 & 0 & 0 & 0 & 0 \\
salmeterol & 6 & 1 & 3 & 9 & 7 & 1 & 1 & 0
\end{tabular}

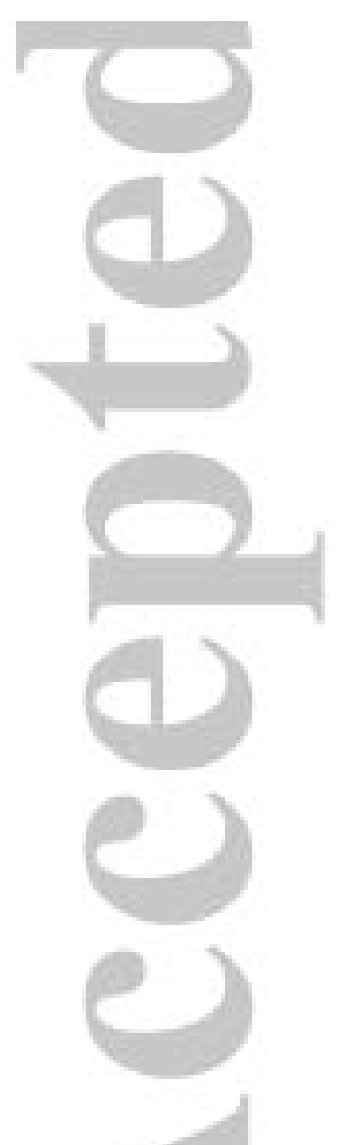




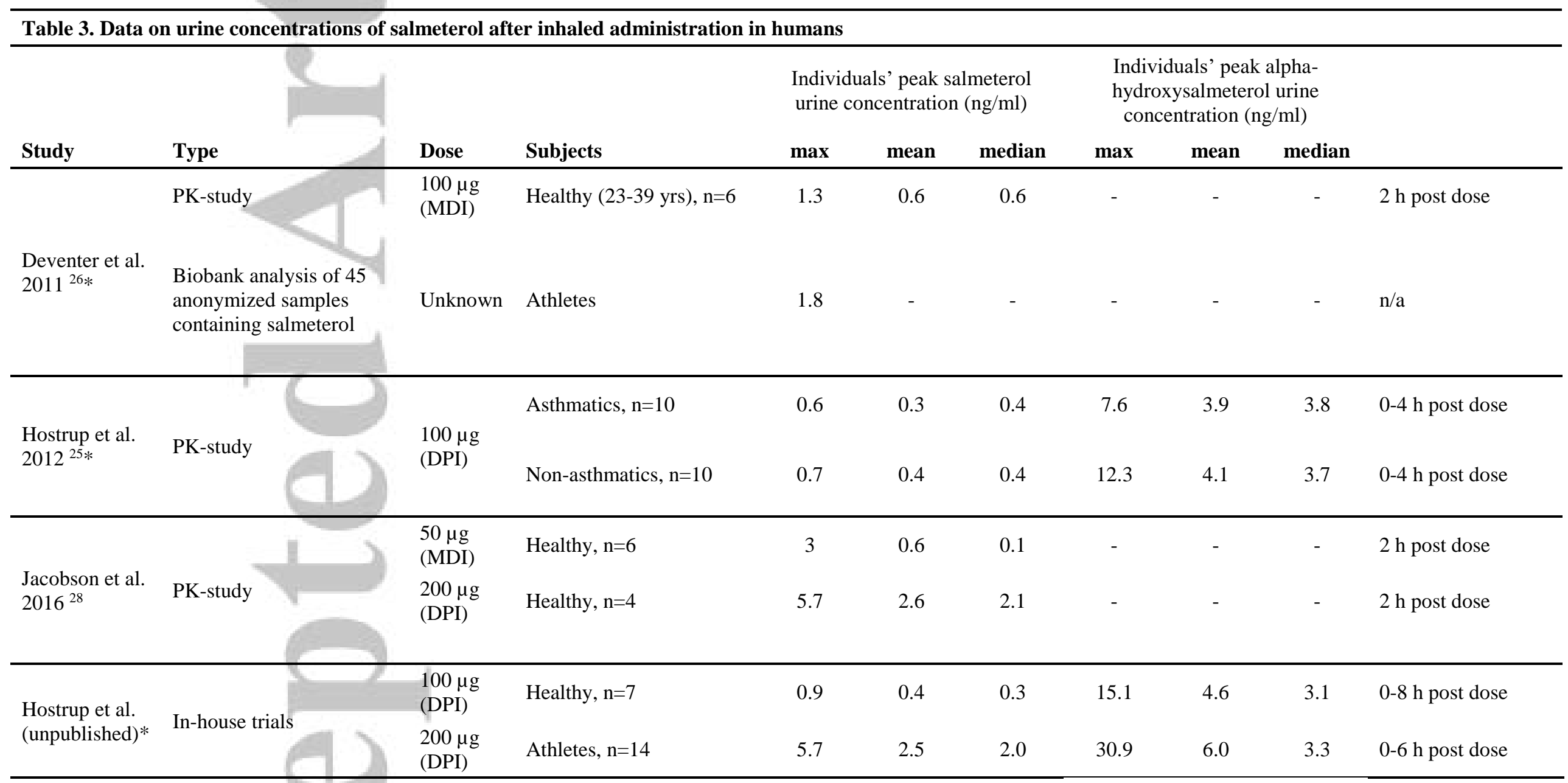

DPI: dry-powder inhalation; MDI: metered dose inhaler; PK: pharmacokinetics. *analysis by WADA accredited laboratory 
A

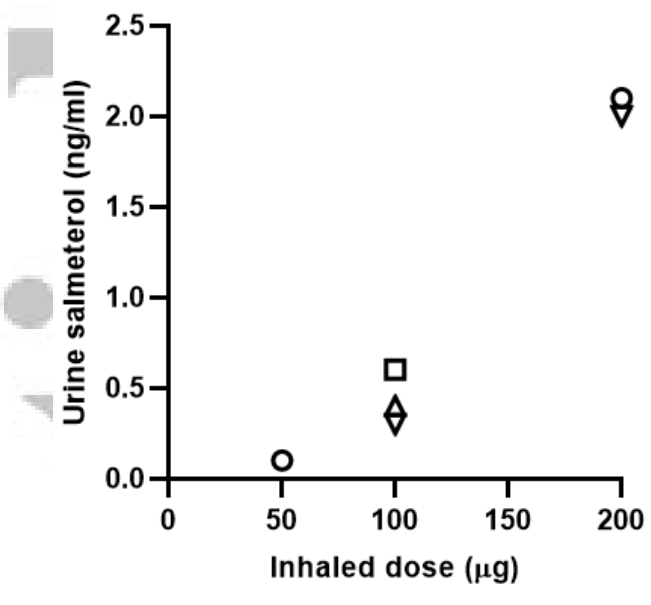

B

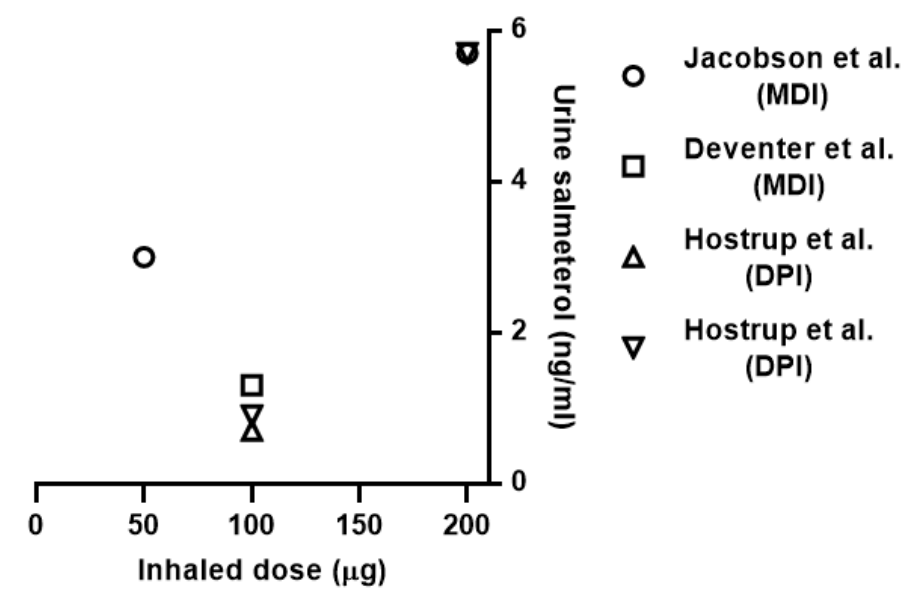

Figure 1. Comparison of median (panel A) and maximum (panel B) free salmeterol urine concentrations from studies reported in Table 3 demonstrating a linear dose-urine relationship for median levels and a non-linear dose-urine relationship for peak concentrations. 